\title{
Dette kommer du ikke til å huske
}

En student spurte meg nylig i en fullsatt sal: «Må vi lese hele kapitlet til eksamen?» Han skjønte ikke vitsen med å lese alt, siden det meste uansett ville bli glemt.

Hva handlet det om, det siste sammendraget du leste? Hvem var førsteforfatter? Og hva sto i diskusjonen? Klarer du å svare på dette, er det imponerende. Mange klarer det ikke. Artikler man leser, kan glemmes fort. Det er dessuten en formidabel oppgave å holde styr på alt som kommer på trykk. Har det da i det hele tatt noe for seg jevnlig å lese forskningsartikler? Dersom forskningslitteraturen ikke blir husket, stemmer det muligens at det aller meste av det som blir publisert, trygt kan overses (1).

Hvorfor er det generelt vanskelig å huske forskningslitteratur? Dette er det vanskelig å svare på, for det finnes en rekke forhold som påvirker evnen til å huske, for eksempel søvn, blodsukkernivå, konsentrasjon, syns- og hørselsfunksjon og mental helse. Når det gjelder leger spesielt, har man også vært inne på tanken at de kan bli lei av å vedlikeholde kunnskapen når de har jobbet lenge innen et fagfelt (2).

For å kunne drive god diagnostikk og pasientbehandling er det nødvendig å ha forskningsbasert kunnskap. Men hva med den forskningslitteraturen som leses av lyst og interesse uten at den har direkte klinisk nytte - har det noe å si om vi glemmer den? $\mathrm{Ja}$, når noen husker nye forskningsresultater innen sitt fagfelt, sier det blant annet noe om vedkommendes faglige holdninger.

Vi forstår fremdeles ganske lite av hvordan den menneskelige hukommelsen fungerer. Selv om modellene for hvordan hjernen lagrer minner gradvis blir bedre, har folk flest utdaterte meninger om hvordan hukommelsen virker (3). Eksempler på dette er at man tror hukommelsen fungerer som et videokamera eller at man kan få bedre hukommelse ved hypnose (3). Vi stoler også mer på minner med sterkt følelsesmessig innhold, men det er det ingen grunn til (4). Minner er alltid rekonstruktive og vil derfor være preget av unøyaktigheter og inneholde små eller store feil (5).

I motsetning til hva mange later til å tro, er det ikke tilstrekkelig kun å repetere det man har lest for å huske det godt. Medisinstudenter husker for eksempel bedre det de har pugget dersom kunnskapen blir testet (6). En annen måte å styrke hukommelsen på er å bearbeide fagstoffet aktivt, for eksempel ved noe så enkelt som å skrive notater (6). Det er dessuten fordelaktig å gjenta innholdet jevnlig uten at det går for lang tid fra første gang det blir repetert (6). Dette er lettere sagt enn gjort i en travel klinisk hverdag - men alle kan ha godt av å trimme de små grå.

Psykolog og nobelprisvinner Daniel Kahneman fortalte om en student som hadde lyttet til en nydelig symfoni i 20 minutter. Mot slutten kom en ulyd og «ødela hele forestillingen» (7). Det var naturligvis ikke ulyden som gjorde det. Studenten hadde hatt en flott opplevelse av symfonien i nær 20 minutter - ulyden ødela selve minnet av opplevelsen. Helsepersonell som har latt seg inspirere av spennende introduksjoner, tankevekkende diskusjoner og illustrative tabeller med attraktive p-verdier, kan sitte igjen med uklare minner, som for eksempel «Diskusjonen var jo temmelig lang, og jeg aner ikke hva de konkluderte med» eller «Jeg mener å tro at studien kanskje bekreftet tidligere funn» eller «Jeg skummet gjennom metaanalysen i forrige uke, men ikke spør meg hva budskapet var». Slik glemsomhet er ganske vanlig og kan også ødelegge minnet av leseopplevelsen og gjøre at man mister lysten til å lese mer faglitteratur.

Min student burde spurt: «Er det nødvendig å repetere fagstoffet på flere måter for så allikevel bare sitte igjen med brøkdeler av kunnskapen?» Svaret er ja, for slik er den akademiske virkelighet. Til tross for at mennesker er født med en intens higen etter læring, setter hukommelsen en naturlig ramme for hva som faktisk kan læres. Allikevel bør fagstoff huskes. Ingen tar skade av å bruke hjernen litt mer - husk det!

\footnotetext{
Litteratur

1. Hem E. For mange tidsskrifter - for lite god forskning. Tidsskr Nor Legeforen 2011; 131: 1871 .

2. Leger holder seg ikke oppdaterte. www.klikk.no/helse/doktoronline/ article483854.ece (14.4.2015)

3. Simons DJ, Chabris CF. What people believe about how memory works: a representative survey of the U.S. population. PLoS ONE 2011; 6: e22757.

4. Laney C, Loftus EF. Emotional content of true and false memories. Memory 2008; 16: $500-16$.

5. Hyman IE Jr, Loftus EF. Errors in autobiographical memory. Clin Psychol Rev 1998. 18. 933-47.

6. Augustin M. How to learn effectively in medical school: test yourself, learn actively, and repeat in intervals. Yale J Biol Med 2014; 87: 207-12

7. The riddle of experience vs memory. www.ted.com/talks/ daniel_kahneman_the_riddle_of_experience_vs_memory/transcript (14.4.2015).
} 